\title{
Seed Harvesting Time Affects Seedling Emergence, Vigour and Growth: Case Study of Rumex turcomanicus Czerep. (Polygonaceae)
}

\author{
Morteza ALIREZAIE NOGHONDAR*, Majid AZIZI \\ Ferdowsi University of Mashhad, Faculty of Agriculture, Department of Horticulture, Iran; mortezaalirezaie@yahoo.com (*corresponding author)
}

\begin{abstract}
Rumex turcomanicus Czerep., belonging to family Polygonaceae, is one of native green vegetable in Northeast Iran. Despite the high consumption, its seed germination and dormancy aspects is inconsiderable. In order to investigate the effects of seed harvesting date on seedling emergence, vigour and growth traits of $R$. turcomanicus Czerep., the seeds were harvested at five different times, i.e., two weeks after fruiting (WAF), 6WAF, 8WAF (mature seeds), 2 month after seed ripening (MASR) and 4MASR, and were sowed immediately, at agricultural college of Ferdowsi university of Mashhad, Iran in 2012-2013. The results was showed that the highest and lowest of seedling emergence percentage, seedling emergence rate, seedling vigour index, seedling fresh and dry weight, seedling root and shoot length, total seedling length and \%final normal seedling (\%FNS) was obtained in the seeds which were sowed 4MASR and 2WAF, respectively. Maximum and minimum of mean emergence time (MET) was observed in the seeds which were sowed 2WAF and 4MASR, respectively. Relationship between \%FNS and MET and between \%FNS and emergence percentage was highly significantly negative (-0.961) and positive (+0.962), respectively. Based on the results of this experiment, it seems that the problem of germination in most of the Rumex turcomanicus Czerep. seeds, is probably due to a kind of morphological dormancy, which is remained in most of the fresh seeds (collected 2WAF), and eliminated in the mature seeds (collected 2MASR). Also dry seed storage of the mature seeds for two months was improved seedling emergence and vigour, significantly.
\end{abstract}

Keywords: dry storage, morphological dormancy, medicinal plant, seedling emergence, vegetable

\section{Introduction}

The family Polygonaceae contains about 800 species which are grouped into 30 genera and distributed widely all over the world (Stastn et al., 2010). The Rumex genus of Polygonaceae has 200 species all over the word, of which 23 species are found in Iran and 10 species in Northeast of Iran (Gholami and Joharchi, 2008). Different species of Rumex genus were utilized due to their biological activities, such as antiviral (Cos et al., 2002), antimicrobial, anti-inflammatory (Getie et al., 2002) and antidiarrheal attributes (Rouf et al., 2002).

Proper establishment of plant species is often dependent on the timing of germination resulted from seed responses to environmental cues (Vazquez-Yanes and Orozco-Segovia, 1996), such as light, temperature and soil moisture that are most favorable to their establishment (Baskin and Baskin, 1998). The seeds may display the dormancy cycle which is the period for maturation to germination (Baskin and Baskin, 1998). Seed germination in different species of Rumex genus had been studied by many researchers. Assche et al. (2002) were studied comparative germination ecology of nine Rumex species. They were reported that the seeds of $R$. acetosa and $R$. scutatus are non-dormant and can germinate immediately after dispersal. The seeds of $R$. acetosella do not germinate in the first season after dispersal, but buried seeds do not show a dormancy cycle; they might germinate in different seasons after exposure to light. Seeds of $R$. conglomerates, $R$. maritimus, $R$. sanguineus and $R$. crispus are undergo a seasonal dormancy cycle, with a low level of dormancy in winter and early spring and a deep dormancy in summer. $R$. maritimus also germinates in summer and autumn on drying muddy soils. The seeds of $\mathrm{R}$ hydrolapathum only germinate on waterlogged soils (Assche et al., 2002).

Breaking of seed dormancy in different Rumex species had been studied by researchers. Seed stratification of $R$. acetosella at 1 to $7^{\circ} \mathrm{C}$ for 20 weeks did not improve germination levels. Scarification increased the germination of dry-stored but not fresh seed. The extent of the scarification needed varies with the thickness of the seed coat. Alternating temperatures between 20 and $30^{\circ} \mathrm{C}$ increased the germination of $R$. acetosella seed compared with a constant $20^{\circ} \mathrm{C}$ (Deschênes and Moineau, 1972). Germination was greater under light conditions than in the dark in $R$. acetosella. In alternating temperatures, seed scarification reduced the light requirement (Grime and Jarvis, 1976). Also, germination was promoted by nitrate in $R$. acetosella (Grime et al., 1988). The effect of light quality on seed germination of two Rumex species was studied by Roberts and Totterdell (1981). R. crispus and R. obtusifolius respond positively to red or white light. Far-red 
light applied for short periods may promote or inhibit germination depending on the timing of the irradiation in relation to temperature change; but long periods of farred inhibit germination (Roberts and Totterdell, 1981). Demirezen Yilmaz and Aksoy (2007), were reported a negative relationship between germination rate and seed age in Rumex scutatus. Maximal and minimum germination percent of seeds occurred 0 and 36 month after seed harvesting (Demirezen Yilmaz and Aksoy, 2007). Rumex turcomanicus Czerep. is one of green vegetable medicinally valuable plant. For many years this plant considered as a subspecies belongs to $R$. tuberosus L. species named $R$. tuberosus var. turcomanicus Rech., but in revision on the genus Rumex $\mathrm{L}$. it was changed as a new species named $R$. turcomanicus Czerep. It was first reported by Czerepanov and accepted as a new species (The Plant List, 2010). It's a tuberose geophyte plant belongs to Irano-Turanian chorological type which distributed in Northeast of Iran especially on slopes of Binaloud mountains (Iran: Khorassan Province) (Ghahreman et al., 2006), where its leaves are highly appreciated and consumed and is popularly known as "Sagh torshak". Despite the high consumption, its knowledge is inconsiderable and no attempt has been performed for its domestication. Previously, reported that dormancy isn't similar in different species of Rumex genus. The study conducted by Assche et al. (2002), on germination requirements, dormancy cycle and longevity of nine Rumex species, has shown that within one genus, rather striking differences were observed in germination ecology. They were stated that different species show the adaptations of the related species to their specific habitat (Assche et al., 2002). Therefore, the aim of this study was to evaluate different seed harvesting times on seedling emergence and growth in Rumex turcomanicus Czerep.

\section{Material and methods}

\section{Experimental site and materials}

The seeds of Rumex turcomanicus Czerep. were collected from a natural site from Noghondar region around Mashhad -North east of Iran- $\left(36^{\circ} 22^{\prime}\right.$ latitude and $59^{\circ} 17^{\prime}$ longitude), in four times include $1 ; 2$ weeks after fruiting (2WAF), 2; 6WAF, 3; 8WAF (mature seeds ) and 4; 2 month after seed ripening (2MASR), which were divided in two groups. The seeds collected from dates of $1,2,3$ and one group of 4 were sowed immediately after collecting and the second group of seeds from date of 4 (which were stored dry for 2 months at $25^{\circ} \mathrm{C}$ ) were sowed 2 months later (4MASR). The experiment was conducted at agricultural college of Ferdowsi university of Mashhad, Iran in 2012-2013.

Emergence tests were carried out in compartmentalized nursery trays containing $50(10 \times 5)$ holes, each measuring $4 \mathrm{~cm} \times 4 \mathrm{~cm} \times 6 \mathrm{~cm}$ (depth), which were filled with $50 \%$ sterilized compost soil $+50 \%$ sterilized sand $(\mathrm{V} / \mathrm{V})$ under light/dark cycle conditions of $16 / 8 \mathrm{~h}$ at $23^{\circ} \mathrm{C}$ and $75 \%$ relative humidity placed in a glass greenhouse. Con- tinuous watering was done to maintain the required moisture for germination.

\section{Data Collection and statistical analysis}

Seedlings were counted when the shoots emerged above the substratum surface. The number of emerged seedlings was recorded daily (seedling rate), and the number of final emerged seedlings (expressed in percentage) was counted after 50 days. The emergence rate was calculated according to Maguire's equation (Maguire, 1962): $\mathrm{M}=\mathrm{n} 1 / \mathrm{t} 1+$ $\mathrm{n} 2 / \mathrm{t} 2+\ldots+\mathrm{n} 50 / \mathrm{t} 50$; where $\mathrm{n} 1, \mathrm{n} 2, \ldots, \mathrm{n} 50$ represent the number of emerged seeds at times $\mathrm{t} 1, \mathrm{t} 2, \ldots, \mathrm{t} 50$ (in days).

Ten seedlings were taken away randomly and seedling growth was measured by estimating seedling root length (SRL), seedling shoot length (SSL) and seedling length (SL), on the fiftieth day after emergence. In addition, fresh weights (SFW) and dry weights (SDW) of the sampled seedlings were taken. Dry weight for each plant was determined after drying the samples in an oven at $70^{\circ} \mathrm{C}$ for 48 hrs. Means of the 10 seedlings were used for the analyses of SRL, SRL, SL, SFW and SDW. The experimental design and statistical analyses were similar to those used for the germination test. Mean emergence time (MET) and seedling vigour index (SVI) were calculated using following formula.

Mean seedling emergence time (MET) calculated according the formula of Ellis and Roberts (1981):

$$
\mathrm{MET}=\sum \frac{\text { number of emerged seedlngs }}{\text { day of counting }}
$$

Seedling vigour index (SVI) using the formula of $\mathrm{Ab}$ dul- Baki and Anderson (1973):

$\mathrm{SVI}=\sum \frac{\text { (Seedling emergence percentage } \times \text { Seedling length }(\mathrm{mm})}{100}$

\section{Statistical analysis}

The statistical analysis was performed using Microsoft Excel (2007) and JMP 8 software and means were compared using LSD test at $\alpha=0.05$. The analysis of variance for percent emergence was performed on arcsine transformed data. Correlation coefficients $\left(\mathrm{r}^{2}\right)$ among different seedling traits were applied by SYSTAT 13 software.

\section{Results}

According to the results, harvesting date was a significant difference on all of the studied traits $(p \leq 0.01)$ (Tab.1).

\section{Seedling emergence percentage (SEP) and seedling emergence rate (SER)}

As it's shown in Fig. 1, the highest and lowest of SEP were obtained in the seeds which were sowed 2WAF (54.44\%) and 4MASR (95.51\%), respectively. Also, maximum and minimum of SER were observed 4MASR (15.32 seedling/day) and 2 WAF ( 0.67 seedling/day), respectively (Tab. 2). 
246

Tab. 1. Analysis of variance (mean of square) of seedling traits of $R$. turcomanicus Czerep, as affected by different seed harvesting times

\begin{tabular}{cccccccccccc}
\hline $\begin{array}{c}\text { Source of } \\
\text { variance }\end{array}$ & df & SEP $^{\dagger}$ & SER & MET & SVI & SFW & SDW & SRL & SSL & TSL & $\%$ FNS \\
\hline Treatment & 4 & $1154.07^{* *+}$ & $158.72^{* *}$ & $295.87^{* *}$ & $10.42^{* *}$ & $0.00538^{* *}$ & $0.000024^{* *}$ & $46.884^{* *}$ & $10.346^{* *}$ & $98.528^{* *}$ & $1828.12^{* *}$ \\
Error & 15 & 9.37 & 0.251 & 1.219 & 0.367 & 0.000376 & $3.539 \mathrm{e}-6$ & 2.2929 & 0.6041 & 5.2480 & 13.87 \\
\hline
\end{tabular}

Note: ${ }^{\dagger}$ SEP, SER, MET, SVI, SFW, SDW, SRL, SSL, TSL and \%FNS are indicated seedling emergence percentage, seedling emergence rate, mean emergence time, seedling vigour index, seedling fresh weight, seedling dry weight, seedling root and shoot length, total seedling length and \%final normal seedling, respectively ${ }^{+1} \mathrm{~ns},{ }^{*},{ }^{* *}$ and ${ }^{* * *}$ are non-significant and significant at 5,1 and $0.1 \%$ probability levels, respectively

Tab. 2. Mean comparison of seedling traits of $R$. turcomanicus Czerep, as affected by different seed harvesting times

\begin{tabular}{ccccccc}
\hline Seed harvesting dates & SER $^{\dagger}$ & SFW $(\mathrm{g})$ & SDW $(\mathrm{g})$ & SRL $(\mathrm{mm})$ & SSL $(\mathrm{mm})$ & TSL $(\mathrm{mm})$ \\
\hline $2 \mathrm{WAF}^{+\dagger}$ & $0.67 \mathrm{~d}^{+\dagger}$ & $0.0536 \mathrm{c}$ & $0.00422 \mathrm{~d}$ & $18.27 \mathrm{c}$ & $10.13 \mathrm{~d}$ & $28.40 \mathrm{~d}$ \\
6WAF & $0.953 \mathrm{~d}$ & $0.0623 \mathrm{c}$ & $0.00575 \mathrm{~cd}$ & $19.67 \mathrm{bc}$ & $9.82 \mathrm{~cd}$ & $29.49 \mathrm{~cd}$ \\
8WAF & $3.37 \mathrm{c}$ & $0.0709 \mathrm{c}$ & $0.00724 \mathrm{bc}$ & $21.53 \mathrm{~b}$ & $11.27 \mathrm{bc}$ & $32.80 \mathrm{c}$ \\
\hline 2MASR & $9.35 \mathrm{~b}$ & $0.1028 \mathrm{~b}$ & $0.00926 \mathrm{ab}$ & $24.61 \mathrm{a}$ & $11.77 \mathrm{~b}$ & $36.38 \mathrm{~b}$ \\
4MASR & $15.32 \mathrm{a}$ & $0.1431 \mathrm{a}$ & $0.01017 \mathrm{a}$ & $26.54 \mathrm{a}$ & $13.87 \mathrm{a}$ & $40.40 \mathrm{a}$ \\
\hline
\end{tabular}

Note: ${ }^{~}$ SER, SFW, SDW, SRL, SSL and TSL are indicated seedling emergence rate, seedling fresh weight, seedling dry weight, seedling root and shoot length and total seedling length, respectively;

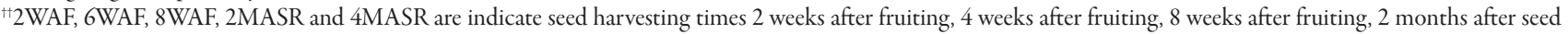
ripening and 4 months after seed ripening, respectively;

${ }^{t+t}$ Similar letters in each column show non-significant differences according to LSD Test at $5 \%$ level of probability

Mean emergence time (MET) and seedling vigour index (SVI)

The highest and lowest of MET were obtained 20.90 and 1.95 days, when the seeds were sowed 2WAF and 4MASR, respectively (Fig. 2). The highest and lowest of SVI were obtained in the seeds which were sowed 4MASR (6.74) and 2WAF (2.82), respectively (Fig. 3).

\section{Seedling fresh (SFW) and dry weight (SDW)}

The highest and lowest of SFW and SDW were observed in the seeds which were sowed 4MASR $(0.1431$ and $0.01017 \mathrm{~g})$ and 2 WAF $(0.0536$ and $0.00422 \mathrm{~g})$, respectively (Tab. 2).

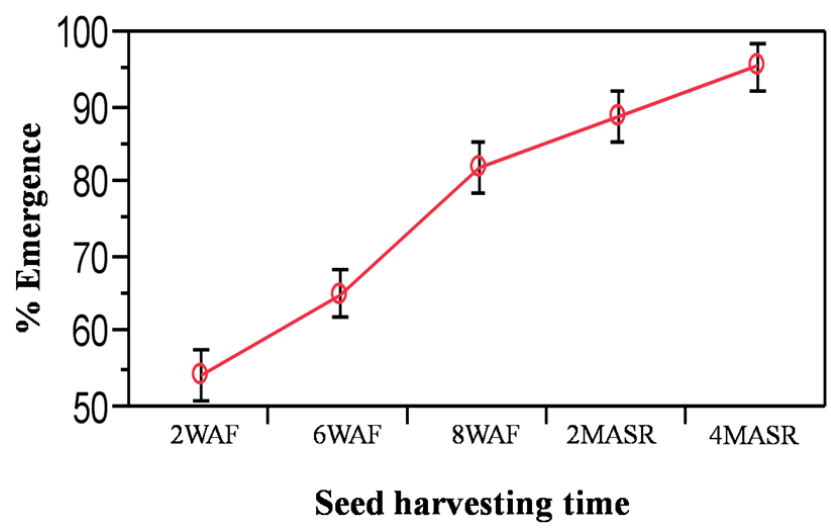

Fig. 1. Effect of different seed harvesting times on mean seedling emergence percentage of $R$. turcomanicus Czerep.

Note: 2WAF, 6WAF, 8WAF, 2MASR and 4MASR are indicate seed harvesting times 2 weeks after fruiting, 4 weeks after fruiting, 8 weeks after fruiting, 2 months after seed ripening and 4 months after seed ripening, respectively
Seedling root (SRL), soot length (SSL) and total seedling length (TSL)

The highest of SRL, SSL and TSL were measured in seed sowing dates at 4MASR, 26.54, 13.87 and $40.40 \mathrm{~mm}$, respectively, and the lowest of these traits were obtained $18.27,10.13$ and 28.40 , respectively, when the seeds were sowed 2WAF (Tab. 2).

\section{$\%$ Final normal seedling (\%FNS)}

Maximum (85.29) and minimum (38.87) of \% FNS was obtained in seed sowing dates at 4MASR and 2WAF, respectively (Fig. 4).

\section{Relationship among seedling traits:}

Correlation coefficients $\left(\mathrm{r}^{2}\right)$ among different seedling traits of the crop are listed in Tab. 3. The $r^{2}$ values of pairs

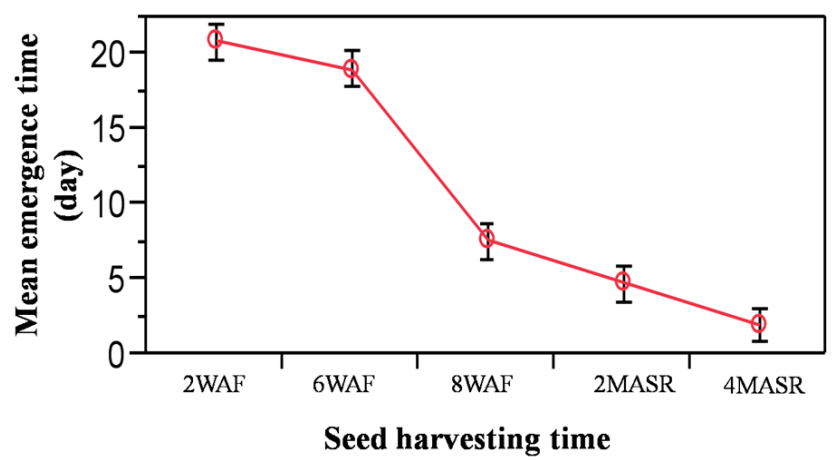

Fig. 2. Effect of different seed harvesting times on mean emergence time in $R$. turcomanicus Czerep.

Note: 2WAF, 6WAF, 8WAF, 2MASR and 4MASR are indicate seed harvesting times 2 weeks after fruiting, 4 weeks after fruiting, 8 weeks after fruiting, 2 months after seed ripening and 4 months after seed ripening, respectively 
Tab. 3. Pearson correlation coefficients $(n=20)$ seedling vigour traits of $R$. turcomanicus Czerep collected in different times

\begin{tabular}{|c|c|c|c|c|c|c|c|c|c|}
\hline Trait & $\mathrm{SEP}^{\dagger}$ & SER & MET & SVI & SFW & SDW & SRL & SSL & TSL \\
\hline SER & $0.87^{* *+\dagger}$ & & & & & & & & \\
\hline MET & $-0.961^{* *}$ & $-0.869^{* *}$ & & & & & & & \\
\hline SVI & $0.926^{* *}$ & $0.905^{* *}$ & $-0.895^{* *}$ & & & & & & \\
\hline SFW & $0.781^{* *}$ & $0.894^{* *}$ & $-0.765^{* *}$ & $0.724^{* *}$ & & & & & \\
\hline SDW & $0.752^{* *}$ & $0.737^{* *}$ & $-0.777^{* *}$ & $0.648^{* *}$ & $0.829^{* *}$ & & & & \\
\hline SRL & $0.825^{* *}$ & $0.897^{* *}$ & $-0.875^{* *}$ & $0.792^{* *}$ & $0.857^{* *}$ & $0.817^{* *}$ & & & \\
\hline SSL & $0.739^{* *}$ & $0.881^{* *}$ & $-0.818^{* *}$ & $0.74^{* *}$ & $0.847^{* *}$ & $0.743^{* *}$ & $0.947^{* *}$ & & \\
\hline TSL & $0.806^{* *}$ & $0.902^{* *}$ & $-0.867^{* *}$ & $0.785^{* *}$ & $0.864^{* *}$ & $0.802^{* *}$ & $0.995^{* *}$ & $0.976^{* *}$ & \\
\hline$\%$ FNS & $0.962^{* *}$ & $0.923 \mathrm{v}$ & $-0.954^{* *}$ & $0.929^{* *}$ & $0.817^{* *}$ & $0.759^{* *}$ & $0.869^{* *}$ & $0.793^{* *}$ & $0.855^{* *}$ \\
\hline
\end{tabular}

Note: ${ }^{\dagger}$ SEP, SER, MET, SVI, SFW, SDW, SRL, SSL, TSL and \%FNS are indicated seedling emergence percentage, seedling emergence rate, mean emergence time, seedling vigour index, seedling fresh weight, seedling dry weight, seedling root and shoot length, total seedling length and \%final normal seedling, respectively ${ }^{+*},{ }^{* *}$ Significant at $5 \%$ and $1 \%$, respectively

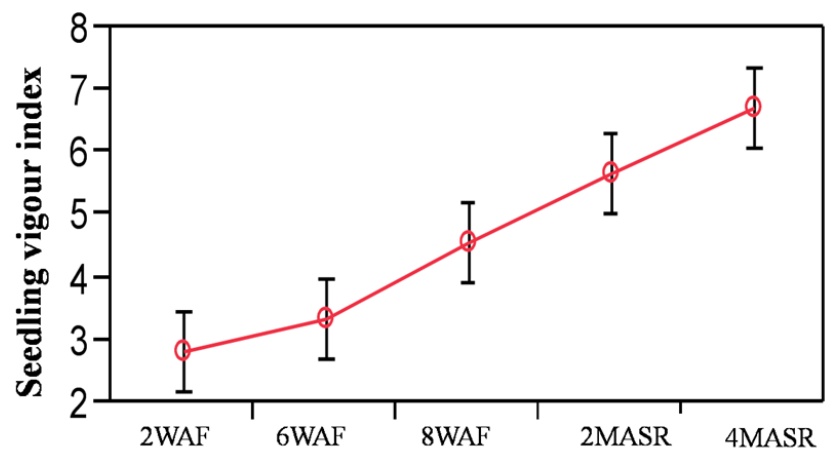

Seed harvesting time

Fig. 3. Effect of different seed harvesting times on mean seedling vigour index in $R$. turcomanicus Czerep.

Note: 2WAF, GWAF, 8WAF, 2MASR and 4MASR are indicate seed harvesting times 2 weeks after fruiting, 4 weeks after fruiting, 8 weeks after fruiting, 2 months after seed ripening and 4 months after seed ripening, respectively

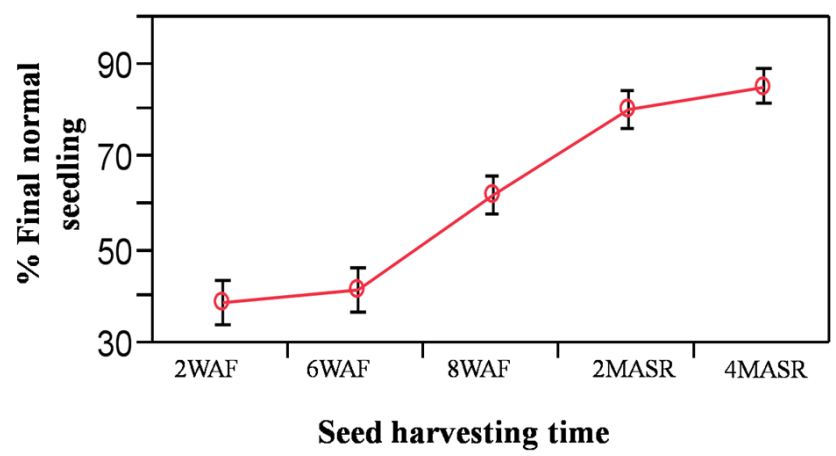

Fig. 4. Effect of different seed harvesting times on mean \%final normal seedling in $R$. turcomanicus Czerep.

Note: 2WAF, 6WAF, 8WAF, 2MASR and 4MASR are indicate seed harvesting times 2 weeks after fruiting, 4 weeks after fruiting, 8 weeks after fruiting, 2 months after seed ripening and 4 months after seed ripening, respectively

of all traits were significant $(p \leq 0.01)$. The association between emergence percentage and other traits was negative. Relationship between \%final normal seedling and mean emergence dates and between \%final normal seedling and emergence percentage was significantly negative and positive, respectively (Tab. 3).

\section{Discussion}

As the results showed, with increasing of seed maturity on mother plant, germination and subsequently seedling emergence as well as other studied characteristics were improved, significantly. The results of this experiment are in agreement with those obtained by Povilaitis (1956), who stated that fresh seed of $R$. acetosella germinated very poorly but germination improved slowly in dry storage. Unlike, the results obtained by Yilmaz and Aksoy (2007), on seed germination of $R$. scutatus, this experiment showed a positive relationship between germination rate and seed age of $R$. turcomanicus.

It seems to be a kind of dormancy in immature seeds that prevent from proper seedling emergence in fresh seeds. In $R$. crispus, which is considered one of the most troublesome weeds, seedlings can emerge throughout the growing season and seeds that remain on the parent plant over winter posses a certain level of dormancy, leading to later and more intermittent emergence compared to the seeds dispersed in autumn (Pye and Andersson, 2008). Trials were carried out to investigate the effects of light and temperature on germination of $R$. obtusifolius. After several months of storage, seeds gradually lost dormancy and became photosensitive. (Benvenuti et al., 2001). According to Asrar (2011), embryos of $R$. vesicaricus seeds have deep physiological dormancy and with $200 \mathrm{ppm}$ gibberellic acid $\left(\mathrm{GA}_{3}\right)$ for $48 \mathrm{hrs}$ at $20^{\circ} \mathrm{C}$ germination promoted through break the dormancy and improving some chemical characteristics of $R$. vesicaricus seeds. Conversely, Bewley and Black (1994) were reported that embryos of $R$. vesicaricus seeds are morpholically immature and thus require a period of further development before they are able to germinate. Such a morphological dormancy may be in the immature seeds (collected $2 \mathrm{WAF}$ ) of $R$. turcomanicus, which is broken with increasing of seed maturity.

\section{Conclusions}

Based on the results of this experiment, it seems that the problem to germination in most of the rumex turco- 
248

manicus Czerep. seeds is probably due to a kind of morphological dormancy, which is remained in most of the fresh seeds, which were collected 2WAF, and eliminated in the mature seeds, which were collected 2MASR. Also dry seed storage of the mature seeds for two months was improved seedling emergence and vigour, significantly.

\section{References}

Abdul-Baki AA, Anderson JD (1973). Vigor determination in soybean seed by multiple criteria. J Crop Sci 13:630-633.

Asrar AA (2011). Seed germination induction of Hommaidh (Rumex vesicaricus L.) by gibberellic acid and temperature applications. Am-Eur J Agric Environ Sci 10(3):310-317.

Assche J, Nerum D, Darius P (2002). The comparative germination ecology of nine Rumex species. Plant Ecol 159:131 142.

Baskin CC, Baskin JM (1998). Seeds: Ecology, biogeography an Evolution of dormancy and Germination. Academic Press, San Diego.

Benvenuti S, Macchia M, Miele S (2001). Light, temperature and burial depth effects on rumex obtusifolius seed germination and emergence. Weed Res 41:177-186.

Bewley JD, Black M (1994). Mobilization of stored seeds reserves. In Seeds Physiology of Development and Germination, Plenum Press, New York and London.

Cos P, Hermans N, Bruyne T, De Apers S, Sindambiwe JS, Witvrouw M, Clercq E, De Berghe DV, Pieters L, Vlietinck AJ (2002). Antiviral activity of Rwandan medicinal plants against human immunodeficiency virus type-1 (HIV-1). Phytomedicine 9:62-68.

Demirezen Yilmaz D, Aksoy A (2007). Physiological effects of different environmental conditions on the seed germination of rumex scutatus L. (Polygonaceae). Erciyes Üniversitesi Fen Bilimleri Enstitüsü Dergisi 23(1-2):24-29.

Deschênes JM, Moineau D (1972). Conditions de germination de quatre mauvaises herbes du Québec. Nate Can 99:103114.

Ellis RA, Roberts EH (1981). The quantification of ageing and survival in orthodox seeds. Seed Sci Technol 9:373-409

Getie M, Gebre-Mariam T, Rietz R, Höhne C, Huschka C, Schmidtke M, Abate A, Neubert RH (2002). Evaluation of the anti-microbial and anti-inflammatory activities of the medicinal plants Dodanaea viscose, rumex nervosus, and rumex abyssinicus. Fitoterapia 74:139-143.
Ghahreman A, Heydari J, Attar F, Hamzeh'ee B (2006). A Floristic Study of the Southwestern Slopes of Binaloud Elevations (Iran: Khorassan Province). JSUT 32(1):1-12.

Gholami AL, Joharchi MR (2008). Revision on the genus Rumex L. in Northeast of Iran, $177-179$ p. In: $15^{\text {th }}$ National $3^{\text {rd }}$ International Conference of Biology, Tehran, Iran, 19-21 August 2008.

Grime JP, Hodgson JG, Hunt R (1988). Comparative plant ecology: a functional approach to common British species. Unwin Hyman, London.

Grime JP, Jarvis BC (1976). Shade avoidance and shade tolerance in flowering plants II, 525-532 p. In: Effects of light on the germination of species of contrasted ecology. Reprinted from: Light as an Ecological Factor. The $16^{\text {th }}$ Symposium of the British Ecological Society, 1974, Blackwell Scientific Publications, Oxford.

Maguire JD (1962). Speed of germination-aid in selection and evaluation for seedling emergence and vigour. Crop Sci 2:176-177.

Povilaitis B (1956). Dormancy studies with seeds of various weed species. Proceedings Intl Seed Testing Assoc 21:88111.

Pye A, Andersson L (2008). Time of emergence of Rumex crispus $\mathrm{L}$. as affected by dispersal time, soil cover, and mechanical disturbance. Acta Agric Scand Sect B Plant Soil Sci 59:500505.

Roberts E H, Totterdell S (1981). Seed dormancy in Rumex species in response to environmental factors. Plant Cell and Environ 4:97-106.

Rouf ASS, Islam MS, Rahman MT (2002). Evaluation of antidiarrheal activity of Rumex maritimus root. J Ethnopharmacol 84:307-310.

Stastn P, Klime L, Klimesov J (2010). Biological flora of Central Europe: Rumex alpinus L. Perspect Plant Ecol 12:67-79.

The Plant List (2010). Version 1. Published on the internet; http://www.theplantlist.org/tpl/record/tro-26002579.

Vazquez-Yanes C, Orozco-Segovia A (1996). Physiological ecology of seed dormancy and longevity, 535-558 p. In: Mulkey SS, Chazdon RL, AP Smith (Eds.). Tropical Forest Plant Ecophysiology, Chapman \& Hall, New York. 